\title{
Hilary E. Wyss \\ English Letters and Indian Literacies: Reading, Writing and New England Missionary Schools, 1750-1830
}

Philadelphia: University of Pennsylvania Press, 2012. 264 pp.

\section{Thomas Peace}

Acadia University

For those of us who teach, an early lesson we learn is that our goals and our students' goals are seldom the same. After a few rounds of marking, the dialogue in which we enter with our students becomes apparent: what we teach is not necessarily what they learn. Teachers may have influence, but outcomes often remain dependent on factors external to the classroom.

This interplay between expectations and outcomes lies at the heart of Hilary Wyss's English Letters and Indian Literacies. The book reveals the contest between colonial and indigenous intellectual traditions that underpins North America's transformation into a colonized space. Taking mid-eighteenth century Congregationalist New England missionary culture and the boarding schools that developed out of it as her central focus, Wyss captures the tensions between anglo-colonial pedagogies, with their emphasis on technical reading and writing skills, and the very different written expression of the indigenous students who attended these schools. Missionary teaching was not the same as indigenous student learning.

Though the book examines a handful of other schools, English Letters focuses on two specific missionary efforts. The first part examines the Stockbridge Boarding School and Moor's Charity School (the forerunner to Dartmouth College) between 1750 and 1770. The latter half looks at the American Board of Commissioners for Foreign Missions' schools in Cherokee country and the Board's Connecticut Foreign Mission School back in New England during the 1810s and 1820s. Throughout the book, Wyss juxtaposes missionary pedagogies and writing about the schools - usually targeted more towards fundraising than student development — with letters written 
by, and exchanged between, the cadre of indigenous students who attended these institutions. In making her argument, Wyss pays careful attention both to missionary and student writing, but also the material culture and lived experiences within the school. Though missionary pedagogies and practices changed with time, students continued to use alphabetic literacy for purposes well beyond missionary goals.

Wyss uses two broad categories to encapsulate missionary desire and student expression: "Readerly" and "Writerly" (6-8) Indians. The cultivation of Readerly Indians was at the heart of missionaries' pedagogical goals and expectations. As a consequence, the Readerly Indian exists solely in missionary writing. Developing from a pedagogy that separated reading from writing and focused more on technique than comprehension, missionaries sought to cultivate passive students who lived up to idealized, abstract, and feminized notions of appropriate behaviour. The missionary narrative, which included carefully selected examples of students' writing, sought to control the Readerly Indian, ensuring the Readerly Indian's behaviour conformed to colonial expectations.

Wyss uses the term Writerly Indian to describe how students appropriated these skills for their own purposes. Sometimes Writerly Indians used their literacy for active resistance, at other times for broader political organizing. This was the case with Samson Occom and Joseph Johnson, two men who attended Moor's charity school, but became more independent indigenous leaders after leaving the school. Other Writerly Indians, such as Cherokee student memoirists, demonstrated a more subtle appropriation of Readerly-focused school tasks. These students repurposed Readerlytasks and expressions to fight against the growing movement for Cherokee removal during the 1820s. Throughout the book, Wyss amply demonstrates that students carefully manipulated notions of race, class and, gender in order to capitalize on colonial society's literary expectations.

In balancing the Readerly and Writerly Indian, Wyss anchors her argument in an emerging literature on indigenous literacies. She challenges us to imagine a far more complex literary landscape where alphabetic literacy is situated among more customary indigenous literacies such as weaving, carving, tattooing, and painting, as well as later innovations such as the Cherokee syllabary. Building upon this foundation, the book remains attentive to the texts students and missionaries produced as well as to the material reality in which they lived. Wyss carefully shapes her argument around objects such as pocket watches, and around the schools' daily routines, in an effort to understand student experience. With this approach, Wyss breaks down the implicit association between reading, writing, and colonial schooling, demonstrating alphabetic literacy's contested nature within indigenous communities.

Despite Wyss's careful attention to the historical record and her broad conception of literacy, the book could have developed the connection between land, schooling, and literacy more strongly. ${ }^{1}$ These schools, and their curriculum, had a very direct role in preparing the way for colonial expansion. Though Wyss emphasizes the role student writing played in maintaining community and identity, and she anchors the idea of the Writerly Indian in Scott Lyons's concept of "rhetorical sovereignty," land and territory could be developed more forcefully if Wyss placed greater attention on 
how these schools, and the Readerly and Writerly Indians associated with them, were deployed as colonial society physically expanded westward.

The territoriality of education during this period is critical to understanding these missionary institutions. This point can be best illustrated by examining the history of Moor's Charity School. Wyss follows most scholars who write about the school in ending her discussion in the late-1760s, when the school was abandoned by Samson Occom and the Haudenosaunee. This event, however, did not mark the institution's end. (It continues today as Dartmouth College.) Though the beginning of Dartmouth College and the school's relocation to New Hampshire in 1770 certainly reoriented interests away from educating indigenous students, the charity school did not wholly cease its original mandate.

To fully understand indigenous engagement with the charity school, one must consider New England's colonial expansion following the Seven Years' War. In 1770, following the British defeat of New France, the school moved from Mohegan to Abenaki territory along with thousands of New England settlers as they flooded northwards into the Upper Connecticut Valley. The new location created a new student body, mostly comprised of Abenaki from Odanak and other indigenous people from the St. Lawrence Valley and Lower Great Lakes. Their numbers were significant. Nearly seventy indigenous students attended the school between 1770 and 1830; three of them graduated from the College. ${ }^{2}$ The school's mandate had not wholly ended, though its focus had substantially reoriented. Although Wyss takes the discussion to this point, it is likely that Readerly and Writerly tropes continued at the school, and it is possible that they shaped the institution and community that Dartmouth and Odanak became.

These criticisms should not discount the important contribution English Letters makes to our understanding of the history of indigenous education and literacy studies. The emphasis on Readerly and Writerly Indians makes an important intervention to the field as a whole and, when read alongside recent books such as Lisa Brooks' The Common Pot and Linford Fisher's The Indian Great Awakening, Wyss's work reminds us that for many indigenous peoples the meanings they found in the skills taught at these schools were deeply anchored in their own more-independent networks and communities. Indeed, the book reveals "the paradox of the mission school with its simultaneous challenge to Native culture and its transgressive potential to maintain it" (31). English Letters and Indian Literacies is a model for those of us interested in moving beyond the colonial biases of the archive and should be read by anyone interested in indigenous history, early American history, or the history of education in North America.

\section{Notes}

$1 \quad$ Wyss develops this elsewhere in Stephanie Fitzgerald and Hilary Wyss, "The Textualities of Native Studies," American Literary History 22, no. 2 (2010): 271-279.

2 Colin Calloway, The Indian History of an American Institution: Native Americans and Dartmouth, (Hanover: University Press of New England, 2010), appendix. 